\title{
Rhythm and its perception in the central nervous system
}

\author{
RIED, B. ${ }^{1}$, RODRIGUES, G. M. ${ }^{2}$ and GAMA, E. F. ${ }^{2}$ \\ ${ }^{1}$ Escola Superior de Educação Física de Jundiaí, Rua Rodrigo Soares de Oliveira, \\ s/n, Bairro Anhangabaú, CEP 13208-120, Jundiaí, SP, Brazil \\ ${ }^{2}$ Department of Physical Education, São Judas Tadeu University - USJT, Rua Taquari, \\ 546, CEP 03166-000, São Paulo, SP, Brazil \\ *E-mail: bried@esef.br
}

\begin{abstract}
Rhythm works as an organizing principle in all sorts/manner of human behavior and perception. Several sciences investigate rhythm, trying to unveil the mechanisms of its perception and its neural correlates. In order to assess the knowledge available from 2001 to 2011 , we conducted a review into five international data bases using the keywords "rhythm" and "perception". 17 original research papers were found whose findings were fairly inconclusive and unable to precisely locate one single rhythm processing area in the brain, but found activations in both cortical and subcortical structures and the cerebellum. However, methods were found to be fairly diverse and often terminologically inconsistent, which hampers comparison between studies. Conclusions: the former vision of rhythm perception in the brain as occurring in a network has been confirmed.
\end{abstract}

Keywords: rhythm, periodicity, perception, central nervous system.

\section{Introduction}

Rhythm is a phenomenon well known to almost all people and extends to all areas of human perception and behavior (SPITZNAGEL, 2000), and perception as well as reproduction of rhythmic patterns are essential for the survival of the human species (BISPHAM, 2006). For several years research has been trying to map which neural structures are activated by rhythmic stimuli, but failed to reveala specific area. Rhythmic perception seems to be distributed over several neural structures (SPITZNAGEL, 2000; ALTENMUELLER, SCHUPPERT, KUCK et al., 2000), similar to what happens in language and memory processes (PEREIRA REIS and MAGALHÃES, 2003), which involve motor and limbic structures as well as the brainstem (LENT, 2010).

Rhythm has been defined as "[...] explicit division of time or space into intervallic systems, recurrent and often (but not always) characterized by periodicity [...]" (THAUT, 2005 , p. 4), emerging from isolated events such like stimuli or pauses. These events, however, only unveil their rhythmic properties when perceived as a whole, a pattern of repeated stimuli and pauses (THAUT, 2005). This pattern can be located in different levels of analysis: we recognize a pulse when perceiving a regular succession of almost identical stimuli separated by pauses of almost identical length. Meter expresses itself by grouping several stimuli and intervals with varying accentuation, groupings which remain almost identical as they repeat themselves. Rhythm in a narrow sense can be seen as the individual variation of metric that carries expression. However, there is no consensus regarding these definitions over the range of sciences that study rhythm. Linguists seem to take rhythm and metric as synonyms (ZHANG, SHU, ZHOU et al., 2010) whereas for musicologists they bear great difference between them (SEIDEL, 1998), as well as they do for sports scientists.
For the latter, pulse, meter and rhythm characterize motor actions: on one hand, rhythm is a major criterium for classifying motor skills (SCHMIDT and WRISBERG, 2001). Once a new skill shows a different rhythm (both timing and stressing of each component of a skill), it will demand the learner to build up a new motor plan prior to execution, whereas changes in force, overall duration and activated muscle groups can be handled by parameter changes to an existent motor program (TANI, 2005). Variations in rhythm make complex motor actions like dance or gymnastics series more lively and interesting. Maintaining a steady pulse is crucial to efficiency in endurance sports like running and rowing, and keeping an adequate metrical accentuation within the single cycles of such actions (steps, rowing cycles) in such sports ensures efficiency (MEINEL, 2007).

Perception and production of rhythm is essential for the human species to survive (RAMMSAYER, 2000; WILTERMUTH and HEATH, 2009; PHILLIPSSILVER and TRAINOR, 2005), in a similar manner as is memory and language. Research with both healthy and cerebrally handicapped participants did show diverse results regarding their perception of rhythmic phenomena (ALTENMUELLER, SCHUPPERT, KUCK et al., 2000; RAMMSAYER, 2000; JAENKE, LOOSE, LUTZ et al., 2000; SPITZER, 2002). Until recently researchers held the hypothesis that rhythmic perception is located predominantly in the left hemisphere, whereas metric perception prevails in the right (ALTENMUELLER, SCHUPPERT, KUCK et al., 2000). Time perception, intimately related to rhythm perception, involves cognitive mechanisms, whereas rhythm is perceived predominantly at subcortical levels. Both processes, time and rhythm perception, share several similarities (RAMMSAYER, 2000), and both seem to be 
linked to a hypothetical central oscillator (MACLEOD, 2012 ) that paces motor actions like gait.

Most of rhythm perception research articles focus on auditory stimuli, although rhythm is not restricted to auditory stimuli. Earlier reviews (ALTENMUELLER, SCHUPPERT, KUCK et al., 2000; SPITZER, 2002) limited themselves to auditory perception. However, for sciences that focus onto motor behavior such as sport sciences and physiotherapy, visual, tactile and even proprioceptive perception may be as important as auditory perception. Not only hearing impaired people can use other perceptual modalities as complement or substitute for auditory and/or visual information (PHILLIPS-SILVER and TRAINOR, 2008). Visceral perception allows one to track biological rhythms like heartbeat or breathing. Even vestibular perception can detect rhythmic patterns (PHILLIPS-SILVER and TRAINOR, 2005, 2008). If on one hand there seems to be some affinity between auditory perception and rhythm perception (PATEL, IVERSEN, CHEN et al., 2005), on the other hand several researchers agree that rhythm perception works by pooling different perceptive modalities. This might be a clue for explaining the difficulty in trying to pinpoint a single neural center of rhythm perception.

Rhythm, being a subject of interdisciplinary interest, has been studied by several areas of knowledge. Morphological studies are fairly recent (ALTENMUELLER, SCHUPPERT, KUCK et al., 2000) but brain mapping technologies have developed quickly over the last decade, which suggests that new findings might be available shortly. In order to gather an overview over these advances in the knowledge about neuro-anatomical structures involved in rhythm perception, we conducted a systematic review into several data bases in order to show advances in the knowledge about the neuroanatomical structures involved in rhythm perception.

\section{Objective}

Analyze the production of knowledge about the neuroanatomical structures involved in rhythm perception.

\section{Method}

A systematic review was conducted into five main electronic data bases: Scopus, Science Direct, Ebscohost, Sport Discus and PubMed, covering the years from 2001 to 2011, with the keywords "rhythm" and "perception" applied to the categories "title, keywords, abstract", comprising all original articles. All returns were checked regarding titles and abstracts, and excluded animal models, research focused on biological, neural, circadian and speech rhythms, the latter except if dealing with perception and its location in the brain. Furthermore articles were excluded whose focus was not on neuroanatomy or which considered gender differences, life phases or specific situations such as pathologies.

The remaining articles were subjected to full text analysis regarding the following items: objective, method and the neural regions and hemispheres activated, in order to compare and integrate the findings.

\section{Results and Discussion}

We obtained 18 returns from Scopus, 41 from Science Direct, 7 from Sport Discus, 4 from Ebscohost, and 34 from PubMed. Application of exclusion criteria cut off all returns from Sport Discus as well as from Ebscohost, reduced the Scopus returns to 13 and those from Science Direct to 4, showing 2 repeated returns. Of the returns from PubMed, 5 remained, 3 of which were repeated. Overall we obtained 17 original articles to be analyzed in detail.

\subsection{Objectives and methods}

All 17 works intended to investigate the cerebral regions and hemispheres involved in rhythm perception. Out of these, four concentrated on cerebral regions independently of hemispheres (MOLINARI, LEGGIO, DE MARTIN et al., 2003; PHILLIPS-SILVER and TRAINOR, 2008; IVERSEN, REPP and PATEL, 2009; LARGE and SNYDER, 2009) but the remaining 13 aimed to identify both regions and lateralization.

Regarding participants and instruments, most studies recruited healthy adults (LIMB, KEMENY, ORTIGOZA et al., 2006; GRAHN and BRETT, 2007; CHEN, PENHUNE and ZATORRE, 2008; PHILLIPSSILVER and TRAINOR, 2008; ABECASIS, BROCHARD, DEL RIO et al., 2009; BENGTSSON, ULLEN, EHRSSON et al., 2009; GRAHN and ROWE, 2009; IVERSEN, REPP and PATEL, 2009; ZHANG, SHU, ZHOU et al., 2010; GRAHN, HENRY and MCAULEY, 2011; HORVÁTH, SCHWARCZ, ARADI et al., 2011; JOMORI, UEMURA, NAKAGAWA et al., 2011), two of them professional musicians (PHILLIPS-SILVER and TRAINOR, 2008; ABECASIS, BROCHARD, DEL RIO et al., 2009) two compared musicians to nonmusicians (LIMB, KEMENY, ORTIGOZA et al., 2006; CHEN, PENHUNE and ZATORRE, 2008) and three studied neurological patients with neurological disorders (ALPHERTS, VERMEULEN, FRANKEN et al., 2002; MOLINARI, LEGGIO, DE MARTIN et al., 2003; MOLINARI, LEGGIO, FILIPPINI et al., 2005). There was a clear predominance of healthy participants, which compromised the overall comparison of results to some degree. On the other hand, the fact that findings did not show relevant differences between healthy and neurologically impaired individuals sustains the assumption that rhythm perception is similar between individuals.

Most studies used neuro-imaging equipment to map neural activation during exposure to stimuli (MOLINARI, LEGGIO, DE MARTIN et al., 2003; LIMB, KEMENY, ORTIGOZA et al., 2006; GRAHN and BRETT, 2007; CHEN, PENHUNE and ZATORRE, 2008; ABECASIS, BROCHARD, DEL RIO et al., 2009; BENGTSSON, ULLEN, EHRSSON et al., 2009; GRAHN and ROWE, 2009; IVERSEN, REPP and PATEL, 2009; ZHANG, SHU, ZHOU et al., 2010; GRAHN, HENRY and MCAULEY, 2011; HORVÁTH, SCHWARCZ, ARADI et al., 2011; JOMORI, UEMURA, NAKAGAWA et al., 2011). Besides this, Grahn and Brett (2007) also mapped neural activation during motor responses whereas Abecasis, Brochard, Del Rio et al. (2009) and Large and Snyder (2009) focused on motor responses in testing procedures, and Phillips-Silver and Trainor (2008) inferred the activated region from the participants' behavior.

Although all studies exposed participants to auditory stimuli, the methods varied greatly. Grahn, Henry and McAuley (2011) compared visual to auditory perception, Jomori, Uemura, Nakagawa et al. (2011) asked participants 
to imagine a stimulus after exposing them to a physically existent sound. Phillips-Silver and Trainor (2008) related auditory to proprioceptive perception. Molinari, Leggio, De Martin et al. (2003) and Grahn and McAuley (2009) employed different rhythmic meters. The article by Large and Snyder (2009) reviewed several works on the neural processes underlying pulse and metric perception, without specifying the perceptual modality.

\subsection{Neural structures}

The same diversity we found in the methodological approach also showed up in the spectrum of neural areas detected by the studies under review. Nine studies found activation that extends to both hemispheres without clear predominance of one of them. While Zhang, Shu, Zhou et al. (2010) and Horváth, Schwarcz, Aradi et al. (2011) found activation only in the right hemisphere, Chen, Penhune and Zatorre (2008) found it only in the left.

Regarding single neural structures, activation was most frequently detected in the temporal lobe (ALPHERTS, VERMEULEN, FRANKEN et al., 2002; LIMB, KEMENY, ORTIGOZA et al., 2006; GRAHN and BRETT, 2007; ZHANG, SHU, ZHOU et al., 2010; HORVÁTH, SCHWARCZ, ARADI et al., 2011) - (Figure l: pink) and the cerebellum (MOLINARI, LEGGIO, DE MARTIN et al., 2003; CHEN, PENHUNE and ZATORRE, 2008; MOLINARI, LEGGIO, FILIPPINI et al., 2005) - (Figure 1: yellow). Other regions were each found to be active/activated in four studies: basal ganglia (MOLINARI, LEGGIO, DE MARTIN et al., 2003; GRAHN, 2009; GRAHN and ROWE, 2009; GRAHN, HENRY and MCAULEY, 2011) the premotor cortex (MOLINARI, LEGGIO, DE MARTIN et al., 2003; CHEN, PENHUNE and ZATORRE, 2008; BENGTSSON, ULLEN, EHRSSON et al., 2009) - (Figure 2: light green) and the supplemental motor area (LIMB, KEMENY,

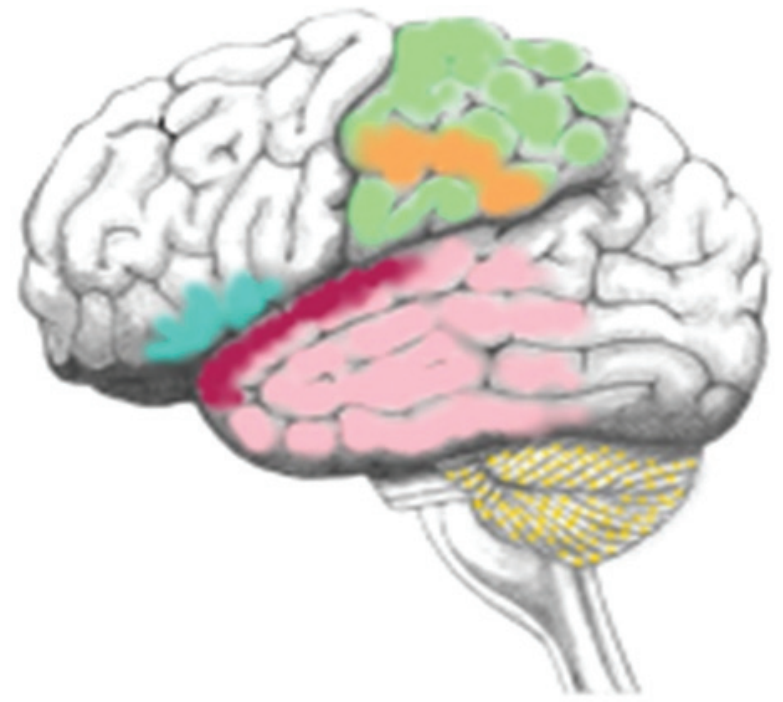

Figure 1. Central nervous system (left lateral view) showing activated areas: temporal lobe (pink), cerebellum (yellow), premotor area (light green), right frontal operculum (blue), left inferior parietal lobe (light orange) and middle temporal gyrus (wine).
ORTIGOZA et al., 2006; GRAHN and BRETT, 2007; BENGTSSON, ULLEN, EHRSSON et al., 2009) - (Figure 2: light blue). Another article reported activation in the left inferior parietal lobe - (Figure 1: light orange) and the right frontal operculum (LIMB, KEMENY, ORTIGOZA et al., 2006) - (Figure l: blue), and in restricted areas within the premotor cortex (Figure 2: light green) and the cerebellum (BENGTSSON, ULLEN, EHRSSON et al., 2009)-(Figure 1: yellow). In the right hemisphere, research found activations in the superior-(Figure 3 : wine $)$ and middle temporal gyrus (- (Figure 3: purple), temporal pole and orbital part of the right inferior frontal gyrus (HORVÁTH,

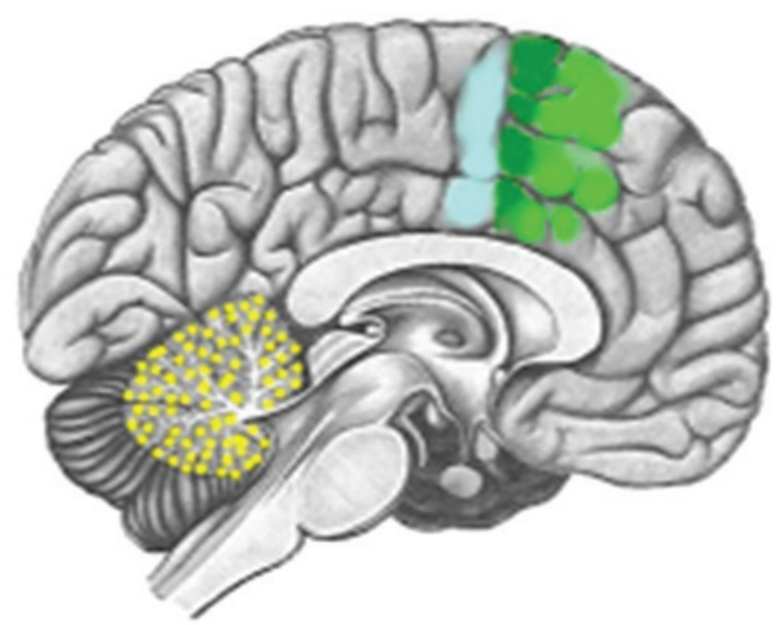

Figure 2. Central nervous system (sagittal view) showing activated areas: motor area (green); premotor cortex (light green), supplemental motor area (light blue), cerebellum (yellow).

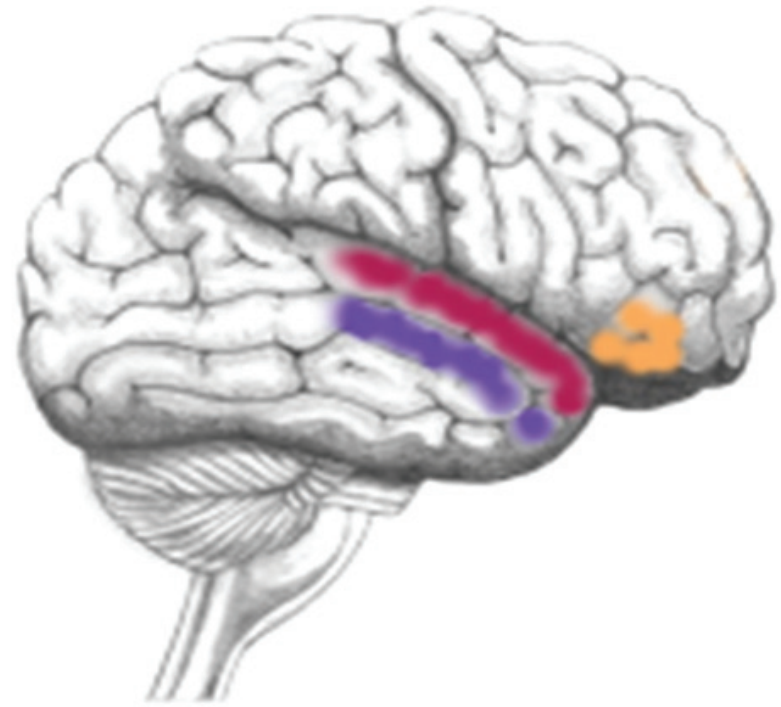

Figure 3. Central nervous system (right lateral view) showing activated areas: middle temporal gyrus (purple), superior temporal gyrus (wine) and right inferior frontal gyrus (light orange). 
SCHWARCZ, ARADI et al., 2011) - (Figure 3: light orange). The left hemisphere showed activation in the frontal region without specifying the area (JOMORI, UEMURA, NAKAGAWA et al., 2011).

Although it was identified in five studies (ALPHERTS, VERMEULEN, FRANKEN et al., 2002; LIMB, KEMENY, ORTIGOZA et al., 2006; GRAHN and BRETT, 2007; ZHANG, SHU, ZHOU et al., 2010; HORVÁTH, SCHWARCZ, ARADI et al., 2011), the temporal lobe seems not to participate in rhythm perception by itself, as shown by Alpherts, Vermeulen, Franken et al. (2002), whose participants registered the same activation pattern even after removal of this neural structure. These findings corroborate the panorama drawn by Altenmueller, Schuppert, Kuck et al. (2000) and Spitzer (2002) indicating that the perception of rhythmic phenomena is processed by a network of neural structures in which superior temporal areas in both hemispheres seem to play a relevant role.

Variations in the rhythmic structure of stimuli lead to diverse consequences in the studies under review. Both metrical and non-metrical stimuli activate the superior motor and pre-motor areas, while the prefrontal cortex is more activated by metrical sequences than by non-metrical sequences. Regular pulses activate the basal ganglia in both hemispheres, and in one case the rhythmical auditory stimulus activated the putamen. This suggests that pulse and meter are perceived in different ways.

A certain inconsistency in the use of terminology hampers the comparison of results. Most authors do not make clear which meaning they ascribe to their variable "rhythm". As shown above, the definitions of rhythm, meter and pulse vary across the fields of study and some take them as synonyms whereas others see them as complementary. This may compromise interpretation of results: although most authors refer to rhythm, in one case the activation of a certain area was due to variation in rhythm in a narrow sense, in other cases this might be due rather to meter or pulse.

We noted the proximity between areas activated by rhythm perception and motor areas. This fact should be taken into consideration in methodological decisions: in several studies aiming to reveal perception, the most easily observable indicator of perception is the reproduction by motor behavior of the perceived rhythm. This testing procedure, however, does not allow one to separate perception and action. In other words, it is not possible to tell whether the activation revealed is due to perception itself or if it is a part of the neural activation related to rhythmic movement.

The results show a high degree of variation regarding neural structures activated, which may be ascribed to individual variations in strategies of information processing in neural structures, as proposed by Spitzer (2002).

\section{Final Thoughts}

This review aimed to map research findings on the brain areas involved in rhythm perception between 2001 and 2011, and corroborates the situation shown in 2000 and 2002. We found that rhythm is a phenomenon whose perception is not limited to a certain neural region or area, but involves a network of cortical and subcortical structures as well as the cerebellum. The studies reviewed discussed rhythm perception and allowed us to infer that the dynamics and diversity of stimulus distribution does not allow one single conclusion. This may be a consequence of the diversity in the procedures taken to present stimuli and to collect data, facts that did not allow homogenization of the sample.

Besides, the proximity between perceptual and motor areas did not ever allow to precisely distinguish between activations caused by perceptual and motor processing, as remarked by Bengtsson, Ullen, Ehrsson et al. (2009). If not aware of this fact, researchers might be misled by this interference when correlating neural structures and rhythmic (re)production. On the other hand, the proximity between motor areas and perceptual areas involved in rhythm perception may give a hint to explain why rhythm, pulse and meter manifest themselves in such a preeminent way in all sorts of motor skills, from speaking through music playing up to sports skills.

The inconsistency in use of terminology (rhythm, meter, pulse) reveals the need to precisely define crucial terms in future research. As for a synopsis, the state of the art in rhythm perception in the brain did not change since 2001, but new procedures and techniques offered different data collection and analysis models which may lead to new discoveries, and might in turn improve reproducibility for the purpose of comparing results.

\section{References}

ABECASIS, D., BROCHARD, R., DEL RIO, D., DUFOUR, A. and ORTIZ, T. Brain Lateralisation of metrical accenting in musicians. Annals of the New York Academy of Sciences, 2009, vol. 1169, p. 74-78. PMid:19673756. http://dx.doi.org/10.1111/j.17496632.2009.04766.x

ALPHERTS, WCJ., VERMEULEN, J., FRANKEN, MLO., HENDRIKS, MPH., VAN VEELEN, CWM. and VAN RIJEN, PC. Lateralization of auditory rhythm length in temporal lobe lesions. Brain and Cognition, 2002, vol. 49, n. 1, p. 114-122. PMid:12027397. http://dx.doi.org/10.1006/brcg.2001.1490

ALTENMUELLER, E., SCHUPPERT, M., KUCK, H., BANGERT, M. and GROSSBACH, M. Neuronale Grundlagen der Verarbeitung musikalischer Zeitstrukturen. In MUELLER, K and ASCHERSLEBEN, G. (Eds.). Rhythmus: ein interdisziplinaeres handbuch. Bern: Huber, 2000. p. 59-78.

BENGTSSON, SL., ULLEN, F., EHRSSON, H., HASHIMOTO, T., KITO, T., NAITO, E., FORSBERG, H. and SADATO, N. Listening to rhythms activates motor and premotor cortices. Cortex, 2009, vol. 45, n. 1, p. 62-71. PMid:19041965. http://dx.doi. org/10.1016/j.cortex.2008.07.002

BISPHAM, J. Rhythm in music: what is it? Who has it? Why? Music Perception, 2006, vol. 24, n. 2, p. 125-134. http://dx.doi. org/10.1525/mp.2006.24.2.125

CHEN, J., PENHUNE, VB. and ZATORRE, RJ. Listening to musical rhythms recruits motor regions of the brain. Cerebral Cortex, 2008, vol. 18, p. 2844-2854. PMid:18388350. http:// dx.doi.org/10.1093/cercor/bhn042

GRAHN, J. The role of the basal ganglia in beat perception. Annals of the New York Academy of Sciences, 2009, vol. 1169, n. 1, p. 35-45. PMid:19673753. http://dx.doi.org/10.1111/j.17496632.2009.04553.x

GRAHN, JA., HENRY, MJ. and McAULEY, JD. FMRI investigation of cross-modal interactions in beat perception: audition primes vision, but not vice versa. Neuroimage, 2011 , vol. 54, n. 2 , p. 1231-1243. PMid:20858544 PMCid:PMC3002396. http:// dx.doi.org/10.1016/j.neuroimage.2010.09.033 
GRAHN, JA. and BRETT, M. Rhythm and beat perception in motor areas of the brain. Journal of Cognitive Neuroscience, 2007, vol. 19, n. 5, p. 893-906. PMid:17488212. http://dx.doi.org/10.1162/ jocn.2007.19.5.893

GRAHN, JA. and MCAULEY, JD. Neural bases of individual differences in beat perception. Neuroimage, 2009, vol. 47, n. 4, p. 1894-1903. PMid:19376241. http://dx.doi.org/10.1016/j. neuroimage.2009.04.039

GRAHN, J. and ROWE, JB. Feeling the beat: premotor and striatal interactions in musicians and nonmusicians during beat perception. Journal of Neuroscience, 2009, vol. 29, n. 23, p. 75407548. PMid:19515922 PMCid:PMC2702750. http://dx.doi. org/10.1523/JNEUROSCI.2018-08.2009

HORVÁTH, RA., SCHWARCZ, A., ARADI, M., AUER, T., FEHÉR, N., KOVÁCS, N., TÉNYI, T., SZALAY, C., PERLAKI, G., ORSI, G., KOMOLY, S., DÓCZI, T., WOERMANN, FG., GYIMESI, C. and JANSZKY, J. Lateralisation of non-metric rhythm. Laterality, 2011, vol. 16, n. 5, p. 620-635.

IVERSEN, JR., REPP, BH. and PATEL, AD. Top-Down control of rhythm perception modulates early auditory responses. Annals of the New York Academy of Sciences, 2009, vol. 1169, p. 58-73. PMid:19673755. http://dx.doi.org/10.1111/j.1749-6632.2009.04579.x

JAENKE, L., LOOSE, R., LUTZ, K., SPECHT, K. and SHAH, NJ. Cortical activations during paced finger-tapping applying visual and auditory pacing stimuli. Cognitive Brain Research, 2000, vol. 10, p. 51-66. http://dx.doi.org/10.1016/S0926-6410(00)00022-7

JOMORI, I., UEMURA, J., NAKAGAWA, Y. and HOSIYAMA, M. Event-related potential study of frontal activity during imagination of rhythm. Journal of Clinical Neuroscience, 2011, vol. 8, n. 2, p. 1687-1689.

LARGE, EW. and SNYDER, JS. Pulse and meter as neural resonance. Annals of the New York Academy of Sciences, 2009, vol. 1169, p. 46-57. PMid:19673754. http://dx.doi.org/10.1111/j.1749$6632.2009 .04550 . \mathrm{x}$

LENT, R. Cem bilhões de neurônios. São Paulo: Atheneu, 2010.

LIMB, CJ., KEMENY, S., ORTIGOZA, EB., ROUHANI, SL. and BRAUN, AR. Left hemispheric lateralization of brain activity during passive rhythm perception in musicians. Anatomical Record Part A: Discoveries in Molecular, Cellular, and Evolutionary Biology, 2006, vol. 288, n. 4, p. 382-389. PMid:16550585

MACLEOD, C. The missing link: evolution of the primate cerebellum. In HOFMANN, MA. and FALK, D. Progress in brain research. Amsterdam: Elsevier, 2012, p. 165-191. PMid:22230627

MEINEL, K. Bewegungslehre Sportmotorik. Aachen: Meyer \& Meyer, 2007.

MOLINARI, M., LEGGIO, MG., DE MARTIN, M., CERASA, A. and THAUT, M. Neurobiology of rhythmic motor entrainment. Annals of the New York Academy of Sciences, 2003, vol. 999, p. 313321. PMid:14681155. http://dx.doi.org/10.1196/annals.1284.042
MOLINARI, M., LEGGIO, MG., FILIPPINI, V., GIOIA, M., CERASA, A and THAUT, M. Sensorimotor transduction of time information is preserved in subjects with cerebellar damage. Brain Research Bulletin, 2005, vol. 67, n. 6, p. 448-458. PMid:16216693. http://dx.doi.org/10.1016/j.brainresbull.2005.07.014

PATEL, A., IVERSEN, J., CHEN, Y. and REPP, B. The influence of metricality and modality on synchronization with a beat. Experimental Brain Research, 2005, vol. 163, p. 226-238. PMid:15654589. http://dx.doi.org/10.1007/s00221-004-2159-8

PEREIRA, J., REIS, AM. and MAGALHÃES, Z. Neuroanatomia funcional: Anatomia das áreas activáveis nos usuais paradigmas em ressonância magnética funcional. Acta Médica Portuguesa, 2003, vol. 16, p. 107-116. PMid:12868388

PHILLIPS-SILVER, J. and TRAINOR, LJ. Feeling the beat: movement influences infant rhythm perception. Science, 2005, vol. 308, p. 1430. PMid:15933193. http://dx.doi.org/10.1126/ science.1110922

PHILLIPS-SILVER, J. and TRAINOR, LJ. Vestibular influence on auditory metrical interpretation. Brain and Cognition, 2008, vol. 67, n. 1, p. 94-102. PMid:18234407. http://dx.doi.org/10.1016/j. bandc.2007.11.007

RAMMSAYER, T. Zeitwahrnehmung und Rhythmuswahrnehmung. In MUELLER, K. and ASCHERSLEBEN, G. (Eds.). Rhythmus: ein interdisziplinaeres handbuch. Bern: Huber, 2000. p. 83-106.

SCHMIDT, RA. and WRISBERG, CA. Aprendizagem e performance motora. Porto Alegre: Artmed, 2001.

SEIDEL, W. Rhythmus (verbete). In FINSCHER, L. (Ed.). Die Musik in Geschichte und Gegenwart. Kassel: Baerenreiter, 1998. p. 257-317.

SPITZER, M. Musik im Kopf. Stuttgart: Schattauer, 2002.

SPITZNAGEL, A. Zur Geschichte der psychologischen Rhythmusforschung. In MUELLER, K. and ASCHERSLEBEN, G. (Eds.). Rhythmus: ein interdisziplinaeres handbuch. Bern: Huber, 2000. p. 1-40.

TANI, G. Comportamento motor: aprendizagem e desenvolvimento. Rio de Janeiro: Guanabara Koogan, 2005.

THAUT, M. Rhythm, music and the brain. New York: Routledge, 2005.

WILTERMUTH, SS. and HEATH, C. Synchrony and Cooperation. Psychological Science, 2009, vol. 20, n. 1, p. 1-5. PMid:19152536. http://dx.doi.org/10.1111/j.1467-9280.2008.02253.x

ZHANG, L., SHU, H., ZHOU, F., WANG, X. and LI, P. Common and distinct neural substrates for the perception of speech rhythm and intonation. Human Brain Mapping, 2010, vol. 31, n. 7, p. 1061116. PMid:20063360. http://dx.doi.org/10.1002/hbm.20922

Received: March 12, 2014 Accepted: July 13, 2014 